\title{
Rob Hartmans
}

De Groene van 1877. Geschiedenis van een dwars weekblad

Amsterdam ( Mets \& Schilt) 2002, 464 p., € 35, IS B N $90533035 \mathrm{I}$ o

Rob Hartmans karakteriseert de Groene Amsterdammer als een 'dwars weekblad' en daarmee is niets te veel gezegd. Vanaf zijn oprichting in I877 wilde het lijfblad van de progressieve intellectueel een stimulerende rol spelen in het politieke en culturele debat. Dat deed het met kracht van argumenten, maar ook met retorisch geweld. 'Zo de hamer niet baatte, nam hij de moker ter hand', schreef J.A. Levy over de eerste hoofdredacteur Jan de Koo. En hetzelfde kan worden gezegd van diens nazaten bij het weekblad; al was ook het floret een geliefd strijdmiddel.

De Groene was én is in alle opzichten een 'auteurskrant'. Tal van grote namen uit de journalistiek en de literatuur werkten mee: Henri Wiessing, Frederik van Eeden, Victor van Vriesland, Sem Davids en Martin van Amerongen, om er een paar te noemen. Het zijn uiteenlopende persoonlijkheden met afwijkende opvattingen. Ze hebben echter gemeen dat ze een intellectuele inslag paarden aan een groot schrijftalent. De Groene wilde diep graven, maar scherpzinnige 
gedachten moesten ook leesbaar, en als het even kon uitdagend, worden verwoord. Zo fileerde muziekcriticus Matthijs Vermeulen in I9Io het spel van een vermaarde violist in even treffende als dodelijke bewoordingen. De man speelde 'met vette, glanzige, welgedane, glibberige breed-uitgestreken toon' en 'zelfgenoegzame, tevredenschommelende, smakelijk-wiegende ritmiek'.

In de beste traditie van de liberale openbaarheid wilde de Groene meewerken aan pluriforme meningsvorming, al had het een sterke voorkeur voor meningen die minder courant waren. Zijn hele bestaan was het vooruitstrevend en daarmee vaak een luis in de pels van de gevestigde elites. In de tijd van Jan de Koo steunde de Groene de radicale liberalen, in de eerste decennia van de twintigste eeuw neigde het naar het socialisme om na de Tweede Wereldoorlog in steeds linkser vaarwater te belanden. Tijdens de Koude Oorlog betuigde het, als enig algemeen-cultureel tijdschrift, sympathie voor het communisme. Omdat het een keuze in het Oost-Westconflict vermeed, leverde dit hem het verwijt op een fellowtraveler te zijn. Met name voormalig medewerker Simon Carmiggelt haalde meerdere malen fel uit in Het Parool.

De jaren na I945 krijgen van Rob Hartmans verreweg de meeste aandacht. Archiefmateriaal was nauwelijks voorhanden en de jaargangen voor I9I8 nam hij uit tijdsoverwegingen niet door. Dat is jammer, want het was interessant geweest iets meer te weten over de opstelling van de Groene in een periode waarin het socialisme opkwam en het liberalisme nieuwe oplossingen zocht om de maatschappelijke problemen het hoofd te kunnen bieden. Zo meldt Hartmans dat het blad veel aandacht schonk aan 'sociale misstanden'. De auteur, die zijn eigen mening vaak niet verbergt, noemt in één zin 'de mensonterende huisvesting', de 'beestachtig lange werktijden', de 'schandalig lage lonen', de 'gevaarlijke en ongezonde arbeidsomstandigheden', de 'nog altijd welig tierende kinderarbeid' en de 'gedwongen winkelnering'. Dat is opmerkelijk. Maar wat de Groene precies schreef, wordt niet duidelijk.

De aanpak en omvang van Hartmans' studie valt in twee delen uiteen. Voor I945 steunt hij voornamelijk op de leggers en werkt hij bepaalde onderwerpen (van na I9I8) uit. Wel is het boek nogal caleidoscopisch; een systematische inhoudsanalyse had meer informatie kunnen geven over zowel de inhoud als de stijl van de Groene in de afgelopen I25 jaar. Na de oorlog concentreert Hartmans zich meer en meer op de werkwijze van de (kleurrijke) redacteuren en de verbeten conflicten die zij in eigen kring en buiten de deur daarover uitvochten. Af en toe lijkt het een soap vol 'massieve betonzeikers' en maakt zich een lichte verbijstering van de lezer meester.

Verreweg de interessantste hoofdstukken van het boek behandelen de jaren zeventig en tachtig, toen de Groene zich ontwikkelde tot een actiecentrum. Volgens redacteur Max Arian moest het blad een 'levendig zenuwcentrum van de linkse beweging' worden. De journalistiek moest 'onderdrukkende structuren' blootleggen en zo bijdragen aan de hervorming van de samenleving. Deze houding kwam tot uiting in de inhoud, die steeds meer in het teken kwam te staan van actiegroepen tegen van-alles-en-nogwat in eigen land en communistische bevrijdingsbewegingen in verre buitenlanden. Zoals Hartmans prettig ironisch opmerkt: 'Zieken, gekken, criminelen, drop-outs en zelfs terroristen zijn in de eerste plaats slachtoffers van de kapitalistische maatschappij en worden net als vrouwen, kinderen, werkende jongeren en studenten onderdrukt door het establishment van middelbare mannen met gevestigde belangen.' De slachtoffers van het kapitalisme krijgen in de Groene alle aandacht. Relativering ontbreekt: 'Het leven is geen lolletje en zolang er nog mensen zijn die uitgebuit en onderdrukt worden, is het zondig om te streven naar ontspanning en schoonheid.' Van een auteurskrant werd de Groene een medewerkersblad. Mooi schrijven was onbelangrijk en zelfs verdacht; het ging om inhoud. De redacteuren hadden een dagtaak aan het vertalen van de onleesbare stukken van allerlei actievoerders naar enigszins begrijpelijk proza.

Maar ook de bedrijfsvoering raakte doortrokken van het linkse gedachtegoed. Op de redactie heerste anarchie, die werd vergroot doordat alle 
personeelsleden, van de jongste bediende tot een oudere redacteur met een gezin, hetzelfde (armzalige) salaris verdienden. Dat wekte op den duur wrevel. Ook de directie ontkwam niet aan het revolutionaire elan. Toen de adresseermachine in I972 van ouderdom bezweek en directeur Van Leeuwen een hypermodern apparaat wilde kopen, stuitte dit op fel protest van redacteur Maarten van Dullemen. Hier was geen sprake van een logistiek, maar van een politiek probleem. Als abonnees nu vrijwillig op woensdagmiddag adresbandjes typten en het blad verzendklaar maakten, zou de band tussen lezer en blad aanzienlijk worden versterkt. Het ideaal van de Groene als zenuwcentrum van al wat links is, zou zo weer een stapje dichterbij komen.

Halverwege de jaren tachtig werd de teloorgang van het revolutionaire ideaal pijnlijk duidelijk. Elkaar beloerende redacteuren vulden het stuurloze weekblad met lectuur die steeds meer uit de tijd raakte. De Verlosser kwam in de persoon van Martin van Amerongen die op organische wijze - zonder conflicten, maar met veel gezag - het woekerende onkruid uit de kolommen verwijderde. Gelijkhebberigheid maakte weer plaats voor liberale openheid; een onderwerp werd weer van meerdere kanten bezien. Artikelen moesten diepgravend zijn, maar ook aantrekkelijk opgeschreven. In zekere zin was de cirkel daarmee rond. Nog immer was de Groene vooruitstrevend, maar het blad was ook weer salonfähig.

Rob Hartmans schreef een mooi portret van een oud en respectabel weekblad, dat met zijn abonneeaantallen immer op de rand van de afgrond balanceerde, maar door zijn excentriciteit altijd een baken in het Nederlandse perslandschap was.

Marcel Broersma 